\title{
Македонија и нејзините соседи
}

\author{
ДРАГИ СтеФанија, Лилијана МиодонСКа \\ Akademia Techniczno-Humanistyczna, Wydziat Humanistyczno-Społeczny, \\ Ul. Willowa 2, PL-43-309 Bielsko-Biała, \\ dstefanija@ath.bielsko.pl,lmiodonska@ath.bielsko.pl
}

\begin{abstract}
Danes ima Makedonija še vedno težek in nezavidljiv položaj - ne priznavajo ji imena, jezika, državotvornosti, politične integritete. Grki zavračajo ime za državo Makedonijo, makedonski jezik in makedonsko zgodovino od Aleksandra Makedonskega do danes; Srbi ne priznavajo makedonske cerkve (kot da je Makedonija poganska država); Bolgari želijo razlagati makedonščino kot bolgarsko narečje; Albanci želijo tretjino teritorialnega ozemlja (zahodne) Makedonije, kjer živi njihova manjšina, priključiti k svoji državi.
\end{abstract}

Many aspirations to conquer Macedonia and to annihilate it have continued into the present. The Greeks have claimed a legal right to the name Macedonia, the Macedonian language and history ever since Alexander the Great. The Serbs do not acknowledge the Macedonian Orthodox Church, as if Macedonia were a pagan country. The Bulgarians claim that the Macedonian language is a Bulgarian dialect, and the Albanians demand one third of Macedonia (the Western part), which is inhabited by an Albanian minority.

Ključne besede: Makedonija, makedonščina, meddržavni odnosi, medkulturni dialog

Key words: Macedonia, the Macedonian language, inter-state relations, intercultural dialogue

1 Македонија како име и територија веќе 3 милениуми е интересна за целиот свет, посебно за балканските соседи. Славата си ја заслужила пред сѐ поради Александар Велики, кого многумина во светотот го викаат Александар Македонски, творецот на првата најголема имерија на три континенти. Со повеќето освоени народи Александар имал добри односи, но не и со своите соседи Грците, Трачаните, Илирите и др. Убаво е да имаш добри соседи и добри односи со нив. Соседите се поблиски од роднините. Тие се до тебе, со тебе, покрај тебе. Со нив имаш меѓа в градина, 
на нива, до зидот, до потокот. Убаво речено, но не е така. Не познавам држава којашто е задоволна со своите комшии, со првите соседи. Да го погледнеме македонското соседство со Грција, Бугарија, Албанија (сега и со Косово), и со Србија.

2 Интересно е да се види грчкото соседство со Турција, Бугарија, Македонија и Албанија, плус големиот дел медитерански острови, во Јонско и Егејско море. Со ниту еден сосед Грција нема братски односи, освен со морето. Да се потсетиме кога пред неколку години за малку не дојде до војна меѓу Грција и Турција, кога двајца турски новинари го ставија турското знаме на безначаен остров во Егејското Море, којшто беше (и уште е) многу блиску до турскиот, а многу далеку од грчкиот брег. Или спорот околу Кипар, како да е само грчки тој остров. Односите меѓу овие две земји се напнати и поради неколкумилионското турско малцинство во Грција, коешто нема достојни малцински права.

Со Бугарија, сега членка на ЕУ и НАТО, Грција има коректни односи и нескриена нетолеранција од историски и престижни причини.

Со Албанија, би рекле, Грција има какви-такви односи и тоа, пред сѐ поради бројното грчко малцинство, коешто има ограничени народни права. Односите и со оваа земја се затегнати.

Со Македонија Грција има само добри и бројни економски односи и многу лоши, да не речеме непријателски политички односи. Грците се бунат поради името Македонија, поради македонската култура, јазик и сѐ што се спомнува како македонско. Зошто е така? Кога во Балканските империјалистички војни Грција доби 51\% од македонската етничка територија, таму остана половина македонско население под грчка окупација. Тоа претставуваше убава половина од основната античка и народна македонска територија. На Македонците во Грција тогаш како и денес не им се признаваат никакви малцински права. За да ја одбранат својата империјална придобивка на негрчката територија, најубаво е да прогласат дека нема Македонци во Грција, дека античките Македонци, претходниците и потомците на Филип II и Александар III Македонски, биле Грци! И уште нешто: нема Република Македонија и сѐ е грчко! Целта на Грците не е само во тоа да се оправда балканскиот империјализам со освоените територии пред 96 години, туку поради најмалку 1,5 милион македонски говорители во северниот дел на Грција (скоро како во РМ и повеќе). Нивното признавање како малцинство, заедно со турското, би значело дека во тој дел од Северна Грција, Грците се малцинство. Грција не си игра со Турција како со Македонија. Македонија е малечка и економски слаба држава. Турција е голема, економски стабилна, воено моќна (иако се заедно во НАТО) држава. Таа е опасен грчки сосед. Македонија е мирољубив сосед и со неа може да си игра дури и со нејзиното име. Се сервира промена на Република Македонија во Република Северна Македонија. Прифаќање на таков диктат од кого и да е значи безусловна капитулација како во загубена војна. Само во војна се поставуваат такви 
услови. Каква е тоа Северна Македонија? Постои ли Јужна Македонија? По Втората војна беше формирана Источна и Западна Германија. Во време на студената војна беа формирани Северна Кореја и Јужна Кореја, Северен Виетнам и Јужен Виетнам. Значи ли тоа дека државата Косово е увертира на некаква Источна и Западна Албанија? На Балканот сѐ е можно, посебно по македонско-албанскиот конфликт во 2001 година, кога со посредство на ЕУ, САД и несреќниот НАТО (кон кого Македонија сака да се приклучи) се случи војна, која покажа дека со Македонија може и со оружје да се игра. Но со името не!

Ако се прифати диктатот Република Северна Македонија, каков што е последниот предлог на медијаторот на ОН во македонско-грчкиот спор, Метју Нимиц, македонскиот јазик ќе се вика северномакедонски јазик, Македонците - Северномакедонци, народната песна би била северномакедонска народна, приказната - северномакедонска, МПЦ - Северномакедонска православна црква, македонската - АРМ би била Армија на Република Северна Македонија, а на 125-те држави, коишто ја признаа Република Македонија под такво име, треба да им речеме: извинете, ние згрешивме и ни рекоа дека сме биле Северна Македонија! Срамота и глупост, нонсенс во името на Грците, коишто повторно го лажат светот тврдејќи дека Македонците во Северна Грција се Грци коишто зборуваат грчки (многумина и турски), коишто пред педесетина години се доселени од Мала Азија. До пред дваесетина години името Македонија беше заборавено во грчкиот вокабулар. Но ако Грците мислат дека под името Македонци се крие мајчиниот јазик како во РМ, тоа е во ред. Но нека им дадат право да се викаат како што се викале уште од прастари времиња. Зашто Грци кои се истовремено и Македонци, не се познати во светот. Речиси сигурно е дека во жилите на македонските Македонци, оние од Северна Грција и од РМ, е останата малку крв од времето на Филип II и Александар III Македонски. Зашто тие не биле Грци. Тие биле жестоки противници на Грците, коишто ги победиле старите Грци и ги уништиле нивните градови - државички. Но тие македонски кралеви не ја уништиле грчката цивилизација, којашто ја прифатиле и натаму ја ширеле по светот. Но поради тоа не се Грци. Оттогаш почнува грчкото непријателство кон се што е македонско. Чудно е тоа како сегашните Грци се гордеат со македонското минато. Со тоа покажуваат дека Грците не се само без страв, туку и почудно, што се без срам! Пред Европа глумат современа мелодрама како модел на опасен евроколонијализам. На грчките лаги и непринципиелните грчки комесари, меѓу кои и францускиот гркољуб Саркози, ги затвораат очите, така како што беа слепи во Букурешт, кога НАТО-вци за прием на Македонија во тој воен сојуз сакаа да се промени народното име. Евромимикрија. Грците, судејќи по сѐ, немаат спор само со својот југ, со морето, плажите, рибите и со раковите, ако не ги броиме немирните морски бранови и силните бури во Средоземско, Јонско и Егејско Море. Античка Грција е темел на европската демократија. Таму настанала богата филозофија и литература, но само од поединци, зашто се- 
кој Грк не бил ниту Есхил, не бил Платон. Таму е создадена историја, која им одговара само ним и на Европа. Грците продаваат квазиисторија кога Македонците ги претставуваат како Грци. Ретко кога во историјата робот е горд со својот господар (робовладетел). За обичните Грци во стариот Рим, посебно во Византија, настанала латинската погогворка: "Graeca fides, nulla fides" (што значи: Грчка вера, никаква (нула) вера, - цитат преземен од филозофот Алберт Базала и неговата Повјест филизофије (Историја на филозофијата), увод, Загреб, 1908. ${ }^{1}$ Историска потврда за такво мислење за Грците е Тројанскиот коњ - подарок, со кого подло ја уништија Троја. Во најново време, кога НАТО ја нападна стеснетата Југославија, Грците, ѓомити добри српски пријатели, први пратија своја фрага на Јадранско море да го блокира излезот на Котарскиот залив!

3 Бугарски соседи се: Романија, Србија, Македонија, Грција, Турција и Црно Море на исток. Со Турција (заедно во НАТО) Бугарите немаат топли односи од исторски и малцински причини; со Романија и Грција натовски и евроуниски држави имаат умерени и не толку топли односи заради стари и територијални прашања, нерешени уште од минатото. Со Србија имаат умерени односи. Во историјата имале неколку војни со променлива среќа.

Со Македонија Бугарија има релативно добри односи. Бугарија прва ја призна Република Македонија под таквио име и така и се обраќа во меѓусебните односи. Со тоа Бугарите добија големи симпатии од Македонците. Во времето на неевропското и нехумано однесување на Грција, кога ја блокира својата северна граница, целата меѓународна размена и животворната нафта одеше преку Бугарија. Таквата бугарска широчина не беше искористена од македонска страна заради југоносталгичарите, пребојадисаните комунисти скриени во социјалистичката партија. Македонските луѓе често одеа во Бугарија во времето на безвизниот режим. Но македонското стопанство не ги искористи можностите за соработка со

1 „Грчката филозофија е дело на поединец

Кога ќе се рече така, веднаш мислиме дека грчкиот народ во целина е образован и мудар како Ариостотел и со племенити чувства како Платон. Делото на напредноте мислители не би бил ништо друго туку одраз на општото мислење. Арно, ама не е така. Оние коишто ја познаваат историјата на грчките народи убаво знаат колку во нивниот јавен живот влијаело ниското непријателство и завист, какво били нивното несогласување, партиските страсти, подмолните мудрувања, какви биле нивните подметнувања и да не речам каква била нивната слаба вера, така што заради тоа настанала поговорката: Graeca fides, nulla fides. Тоа значи дека грчката филозофија, најчесто е дело на поединец, којшто ја надминал средната мерка на обичниот човрк и станал голем мислител со својата племенитост, и во борба со тогашните разбирања фтасал до зрела општа култура: поединецот со мнозинството заедно работаат на развој ма просветата и со тоа историјата „на грчката фолозофија покажува општ, но многу личен белег на целиот духовен живот." 
бугарското стопанство. Сега, со новиот берлински sид - визниот режим, дури и приватните иницијативи и слободно движење се намалени.

Еден од проблемите со Бугарија е македонското малцинство во Пиринскиот дел на Македонија. На тоа малцинство, кое остана по Балканските војни ${ }^{2}$ (околу 250.000 жители), не му се признаваат малцинските права. По Втората војна Македонците од Пирин имаа свои училишта, театар, библиотеки, книжарници, коишто беа укинати по споророт на Југославија со источниот блок (Информбиро). Најголема национална штета тогаш претрпе точно Македонија.

Проблеми со Бугарија се јавуваат и во културната и просветната сфера. Бугарската лингвистика го смета македонскиот јазик за свој бугарски дијалект, а сето тоа се поврзува и со разни книжевно-историски моменти од времето на Свети Кирил и Методиј, св. Климент, па сѐ до собирачите на македонскиот фолклот: браќата Миладиновци, Марко Цепенков и др. Во последно време прашањето се подгрева во високите кругови, иако се забележува некаква скриена толеранција, барем кај бугарските лингвистички кругови. Но при средбите на високи македонски и бугарски делегации разговорите се водат на двата јазика со преведувачи.

4 Со Албанија, Македонија главно има коректни односи. Таа, како и Србија се две држави во кои Македонците можат да одат без визи. Тоа важи и обратно. Додека Бугарија, а и Србија ја признаа државата како што сама се нарекува Република Македонија, Албанија, од неразбирливи причини ја призна под името БЈРМ- Бивша Југословенска Република Македонија. Проблем е мешањето на официјална Тирана во правата на албанското малцинство во Македонија, посебно по антимакедонскиот албански територистички напад во 2001 годнина, којшто заврши со потпишување на Охридскиот договор. Но Албанците во Македонија постојано имаат нови и нови барања, а нив ги поддржува официјалната власт во Албанија. А правата на бројното македонско малцинство во Албанија (коешто според податоците на македонските културни друштва брои околу 450.000 жители) се елементарни, посебно политичките и јазичните. Таму Македонците немаат ни 100-ти дел од правата, какви што и имаат Албанците во Македонија! Чудни мерила!?

5 Со новонастанатата држава создадена со бомбите на НАТО, САД и ЕУ, Македонија под притисок на САД ја призна државата. Се означи и границата, којашто некои косовски Албанци, на некои места веднаш и ги уништија граничните ознаки за да можат да крадат дрва по македонските планини и да шверцуваат цигари, оружје, дрога и луѓе. Инаку Македонија

2 Бугарите како казна зашто ја предизвикаа Втората балканска војна, при поделбата на пленот добија најмал дел од Македонија (11\%), иако бугарската војска беше најбројна и на најголем турски удар и таа извојува многубројни победи. 
со Косово има развиени трговски односи и со таа земја има позитивен финасиски однос.

6 Со Србија Македонија има добри односи и безвизен режим. Има богата економска соработка и коректни политички односи. Такви беа односите во времето на Титова Југославија, потоа на стеснетата Југославија и сега со самостојна Србија. Како ќе биде понатаму со македонското изнудено признавање на Кососво - не се знае.

Македонија, односно Македонската Православна Црква (МПЦ) има стар спор со Српската Православна Црква (СПЦ). Таа не ја признава автокефалноста (самостојноста) на МПЦ. Тоа се влече од времето на Балканките и Првата светска војна, кога Србија освои 35\% од територијата од денешна РМ, а со тоа македонските цркви ги приклучи кон српските. Спорот не доживеа напредок во времето на цела Титова Југославија. СПЦ за да ги приклучи македонските кон српските цркви и плати на Цариградскта патријаршија поголема свота злато. Тој спор, навидум духовен, се подгрева во кризно време, какво што е денешново.

7 Како што се гледа, сите соседи имаат свои побарувања кон малечката и немоќна Македонија. Грците, коишто во 4. век п.н.е. беа жртви на македонските кралеви Филип и Александар, своите крвници ги прогласуваат како историска гордост. Тоа го чинат сега, кога ги нема и не се плашат од нив. Но се плашат од денешниве Македонци, некакви далечни потомци, коишто и денес го носат тоа славно историско име. А Грците, коишто ја претставуваат македонската историја како своја, не чинат ништо чудно. Таков е нивниот табиет, бесрамен и безобразен. Затоа бараат да се уништи името Македонија, за да можат, како пред дваесетина години тоа име да го забранат кај нив и потоа да го заборават. Ама Македонците се живи и тука, со свои земја, држава, јазик, литература, култутра, историја и проблеми. Независно колку крв тече во жилите на античките Македонци, денешниве Македонци се горди на своето име и нема да го дадат. Ако се врши меѓународен притисок за промема на името, се плашам да не почне некаква тајна пресметка како пред Илинденското востание, којашто ја потресе Турската империја.

Бугарите пак, гледајќи ја матната политичка ситуација, поставуваат барање за признавање на бугарско малцинство во Македонија, иако такви права не му даваат на македонското малцинство во Пиринскиот крај.

Српската политика и држава последниве половина век како и денес не покажале никакаво внимание да се реши црковниот спор, туку финансиски ја помагаат паралелната Охридска архиепископија, којашто со српски благослов ја основаа македонски црквени дисиденти. Инаку, екомските односи се коректни и богати..

Албанија мирно ја гледа немирната македонска национално-политичка арена. Можеби смета дека РМ како дел од бивша Југославија (како што самата ја призна -БЈРМ) ќе се распадне како последна југословенска земја. 
Косово пак нема ниту можност, ни моќ за да ја дестабилизира Македонија. Но сепак може да демне и со помош на други да добие дел од Македонија, како што доби цела држава на чинија!

Општо речено, Македонија денес повторно е буре барут на Балканот, коешто може да избувне секој момент.

8 И за крај. Македонија ја признаа 125 држави (од 190 во ОН) со име Република Македонија, дури 4 најголени и најсилни: Русија, Кина, САД и Индија (речиси половина луѓе на земјава). Не знам зошто македонските политичари не го постават името на гласање пред Генералното собрание на $\mathrm{OOH}$ !

Македонија во последно време ги бара своите пријатели по светот. Тие всушност сами се јавуваат, декларирајќи дека се потомци на Александар Македонски од времето на походот во Азија и Африка од неговите војници и офицери, коишто се вљубиле во тамошните убавици, останале таму и имале пород. Летоска Македонците ги пречекаа своите роднини од североистичниот дел на Пакистан - Хунзите на чело со принцот на племето Мир Газанфар Али Кан и неговата жена принцезата Рани Атика. Племето Кафра од Авганистан, според нивната над два милениумска традиција, се сметаат за Македонци. Народот, којшто се вика Минангхазбу од полустровот Суматра (Индонезија) и брои околу 4 милиони и уште три милиони расеани по Малезија, на Филипини, Брунејските острови себе се сметаат за дирекни потомци на најмладиот син на Александар Македонски. Главниот град на индонезиските Македонци е Паданг во Индискиот Океан. Во Кенија - Африка живее племе наречено Туркана, православни христитјани, високи и силни како Александровите војници, коишто прикажуваат дека Македонците им помогнале во борбата со соседите и ги научиле да изработуваат копја, коишто до денес ги викаат Копје на Александар.

Тие племиња расеани по цел свет никој не ги научил дека се потомци на Александар Македонски, а најмалку денешната (безмоќна) македонска пропаганда или наука. Можеби тука најголемо влијание има тамошната народната легенда опевајќи го првиот најславен војсководач во светот. Но тоа е прашање на долготрајни научни испитувања. Несомнено е дека над двомилеумскиот спомен во свеста на старите азиски и на дел африкански племиња или народи не може да биде без никаква реална основа. Нешто морало да биде. А можеби тоа е слична рефлексија како кај некои племиња од Централна Азија, коишто себе си се сметаат потомци на славниот Монголец Џингис Кан.

Треба да се спомне дека некои азиски племиња во пакистанско-авганистанско-индискиот триаголник се многу непријателски расположени не само кога ќе се спомне името Александар Македонски, туку од самото име Македонија. Нив така сигурно не ги воспитале Грците. 
9 Прашањето за промена на името на Македонија е слично на потпишување на безусловна капитулација, ама сега во мир. Македонија не е војнички силна држава, ама е слободна и независна. Грците се однесуваат кон Македонците како кон свои робови. ${ }^{3}$ Тоа не е ништо друго туку злочин кон еден народ. Скоро 2 децении се води тој спор и светот почнува да и се смее на грчката твдоглавост. А ЕУ театрално гледа и ништо не прави, туку притиска само на Македонија. Светот се промени, а Европа не го почитува сопственото римско право и се држи на американското каубојско право.

Допишано.

Мене како студент на мојот друг факултет - правен (дотуркав до 3. година), мојот професор и пријател лингвистот Крум Тошев ме праша кој испит го подготвувам. На мојот одговор дека ќе полагам Кривично право, професорот повторно ме праша: „Дали постои правничко криво?” Такво право можеби постои кај Грците. Тие во стариот век имале филозофија, литература, реторика, ама право како Римјаните - не. Правото било обичајно. Обичаите се менуваат. Така како што се менува меѓународното право денес. Играта со Македонија и нејзиното постоење ќе покаже каде оди денешниот свет. Треба да се откажеме од европоцентичниот светопоглед и да видиме како изгледа останатиот свет, светот на Азија, Африка, Јужна Америка, нивната историја, филозофија, култура. Новиот свет доаѓа. Мора да се менува историјата, светопогледот, односите. Кинескиот колос е веќе во Европа и Америка. Таква е новата реалност.

\section{MAKEDONIJA MED BALKANSKIMI SOSEDI}

Makedonija je kot ime in teritorij zanimiva za svet skoraj tri tisoč let, še posebno za balkanske sosede. Njeno ime je znamenito, hkrati pa kamen spotike zaradi Aleksandra Velikega (ali Aleksandra Makedonskega), prvega voditelja imperija na treh kontinentih; to je postal pred 2300 leti, vse do danes pa njegovega pomena, pa naj gre za vojaško-strateškega, organizacijsko-administrativnega, kulturnega ali političnega, še nihče ni prekosil. Makedonija se po Aleksandru Makedonskem omenja v rimskem času v Bizancu, nato s prihodom Slovanov in Turkov v ta prostor, pa vse do konca balkanskih vojn, ko je bilo ozemlje razdeljeno med Grčijo, Srbijo, Bolgariji in novo nastalo Albanijo.

Danes ima Makedonija še vedno težek in nezavidljiv položaj - ne priznavajo ji imena, jezika, državotvornosti, politične integritete. Grki zavračajo ime za državo Makedonijo, makedonski jezik in makedonsko zgodovino od Aleksandra Makedonskega do danes; Srbi ne priznavajo makedonske cerkve (kot da je Makedonija poganska država); Bolgari želijo razlagati makedonščino za bolgarsko narečje; Albanci želijo tretjino

${ }^{3}$ Грците во септевмри годинава (2008) имаа војнички вежби на неколку километри од македонската граница во околината на Лерин, близу до Битола. 
teritorialnega ozemlja (zahodne) Makedonije, kjer živi njihova manjšina, priključiti k svoji državi.

Po grškem »demokratičnem « modelu so Makedonci nezgodovinski narod, saj naj bi bila Aleksander Makedonski in njegov oče baje Grka; Srbi si lastijo makedonsko pravoslavno cerkev, čeprav je makedonska cerkev ustanovila srbsko; Bolgari povsem zavračajo makedonski jezik, kot da le-ta sploh ne bi obstajal kot knjižni; Albanci odkrito zahtevajo velik del makedonskega ozemlja (npr. oborožen poseg leta 2001). Vse to pa se dogaja pred očmi Evropske zveze in ZDA kot novega imperialnega gospodarja vseh celin. 